\title{
LANDSLIDING AS A LIMIT TO POSSIBLE TERRITORIAL DEVELOPMENT IN THE KYSUCE REGION
}

\author{
MÁRIA BARANČOKOVÁ, PETER BARANČOK
}

Institute of Landscape Ecology, Slovak Academy of Sciences, Štefánikova 3, P.O. Box 254, 81499 Bratislava, Slovak Republic; e-mail: maria.barancokova@savba.sk, peter.barancok@savba.sk

\begin{abstract}
Barančoková M., Barančok P.: Landsliding as a limit to possible territorial development in the Kysuce region. Ekológia (Bratislava), Vol. 38, No. 4, p. 301-317, 2019.

The growing development of settlements in mountainous areas and their sustainable development constantly requires new approaches to assess the land in terms of occurrence of landslides. The flysch zone, where the monitored area is located, is one of the most landslide prone areas in Slovakia. Landslides respond sensitively to the quality of the individual factors that form the landscape and to the change of natural conditions. Their occurrence is a geo-barrier that reduces or totally prevents the use of natural environment and negatively affects the life of population and territorial development. The reason for the increased hazard of landslides is not only demographic pressure on territories, but also its poor management. Consistent spatial planning addresses not only the spatial layout but also the functional use of the territory. Landslides represent one of the limits of land use. This study is based on the assessment of landsliding as a limit to possible territorial development. The input parameters for the assessment were elements of the current landscape structure (built up structure, forest stands, transitional woodland-shrubs, traditional agricultural land, permanent grasslands and arable land) and occurring landslides (active, potential and stabilized). On most of the determined elements of the landscape, landslides occur on about a quarter of their area. They have a smaller share only in areas of mixed forests, built up areas and have the smallest share on arable land. Potential landslides have the largest proportion on all landscape elements. They occupy the largest areas on coniferous forests (1578.93 ha) and on permanent grasslands (741.33 ha). By evaluating the overall endangerment of the area by landslides according to the degree of threat, we found that the greatest threat of landslides is in the Skalité and Svrčinovec cadastral areas, the smallest threat is in the Čadca cadastral area. In addition to the danger of landsliding in the individual elements of the landscape, we have also set limits for its development. Spatial planning limits have been divided into two categories according to the sectors they affect the most: limiting the development of an area assigned for residential building, or restricting the development of an area designed for agricultural and forestry purposes.
\end{abstract}

Key words: landsliding, territorial development, current landscape structure, flysch area, territorial stability.

\section{Introduction}

More than 15,000 of the potential landslides (which is $63 \%$ of all landslides in Slovakia), which cover an area of about $1620 \mathrm{~km}^{2}$, have been registered in Slovakia by regional research. These landslides are mainly concentrated in flysch highlands, in the intra-mountain basins and at the edges of the young volcanic mountains (Malgot, Baliak, 2002). 
The Kysuce region is characterized by the occurrence of various geodynamic phenomena, which can be understood as a geo-barrier reducing or completely hampering the use of the natural environment and negatively affecting the life of society and territorial development. Each slope has some degree of stability. Its reduction is due to the impact of a natural factor, for example, precipitation and temperature anomalies, weathering of rocks due to exogenous agents, gradual slope loading, uneven slope destruction, seismic shocks, slope inclination, flow erosion, and so on. In addition to natural factors, human activity also plays an important role.

The further development of settlements in mountainous areas with hilly character and their sustainable development requires new approaches to the studies of landslide threats (Bathrellos et al., 2009; Mancini et al., 2010; Guillard, Zêzere, 2012). In the last decades, occurrence of landslides has been constantly increasing in the world. The reason for this increased risk is not only demographic pressure on territories, but also its poor management. Some countries have already made progress in developing the management practices of population growth and minimizing the risks associated with them. Geographic Information Systems (GIS) and Earth Remote Sensing have become integral tools for assessing natural hazards. In addition, GIS is a useful tool for spatial analysis of landslides and for mapping sensitivity of the territory to landslides (Bathrellos et al., 2009; Lan et al., 2004). Improving urban planning and development by zoning of risks and hazards using new technologies and mathematical modeling, while working on the field, is also an important part and is dealt by Cascini et al. (2005). An important parameter for predicting and managing natural disasters is the assessment of landslide hazards. It is also a necessary step for natural and urban planning in government policies around the world (Lekkas, 2000, Carrara et al., 2003; Nowak, Tokarczyk, 2013). The legal and economic consequences resulting from changes of the local spatial plan related to the qualification of landslide areas are analyzed in Bydłosz, Hanus (2013). Landslide areas have limited use for new investments, including construction of buildings, as they are threatened by geological and gravitational slope forces. Spatial planning is a key element in the sustainable development of each country.

An important task in the territorial development is to assess the security of the territory for its development, where it is necessary to consider the amount of input data and factors that can significantly affect these data, especially time and place (Řehák et al., 2013). The evaluation is based on promoting a proactive approach to environmental safety.

Elaboration of maps of areas prone to landslides may be an auxiliary material in the urban planning process in the regions (Mihai et al., 2014; Barančoková, Kenderessy, 2014). This process is important because maps of areas prone to landslides provide a simple tool to inform and control planning and decision-making processes in relation to the new development of proposals within an existing built-up area.

\section{Material and methods}

This study is based on the assessment of landsliding as a limit to possible territorial development. The input parameters for the evaluation were elements of the current landscape structure and the occurring landslides. Elements of current landscape structure were processed by combined method, visual interpretation of aerial orthophomaps, field verification and subsequent processing in GIS environment. The following elements were processed (Fig. 1): 
a. Built up area/structure, resp. settlement - is a complex system in which the settlements of various functions and sizes act distributed in its territory. At present, the notion of the settlement structure is often identified with the structure of municipalities, which form the basic territorial element of public administration and, at the same time, the self-governing community of residents permanently residing in their territorial district. It occupies $4.3 \%$ of the area.

b. Forest stands - include coniferous, deciduous and mixed forests. Forest stands occupy $43.2 \%$ of the territory, the largest representation have coniferous forests, which cover up to $39.7 \%$ of the territory.

c. Transitional woodland-shrub - represented by young forest trees planted after excavations or calamities, natural developmental forest formations, shrubby formations on abandoned meadows and so on. They occupy $13.3 \%$ of the territory in the monitored area.

d. Permanent grasslands (PG) - include meadows and pastures which are a very important phenomenon in the agricultural landscape. They can be characterized as semi-natural, secondary grass-herb formations created in the primary forest zone by human activity (cutting, burning, intentional grazing and mowing) and at the same time are the living space of a number of microorganisms and animals belonging to this complex natural community. They occupy $21.2 \%$ of the area.

e. Traditional agricultural landscape (TAL) - reflects the long-term interrelation between man and country and is represented by strip fields alternating with meadows and pastures, separated by buffer strips or scrub vegetation. It occupies $15.1 \%$ of the area.

f. Arable land - in the form of large intensively managed areas (large-scale arable land) is situated in the lower parts of the slopes or on the floodplains of the main streams of the area. It occupies only $1.7 \%$ of the area.

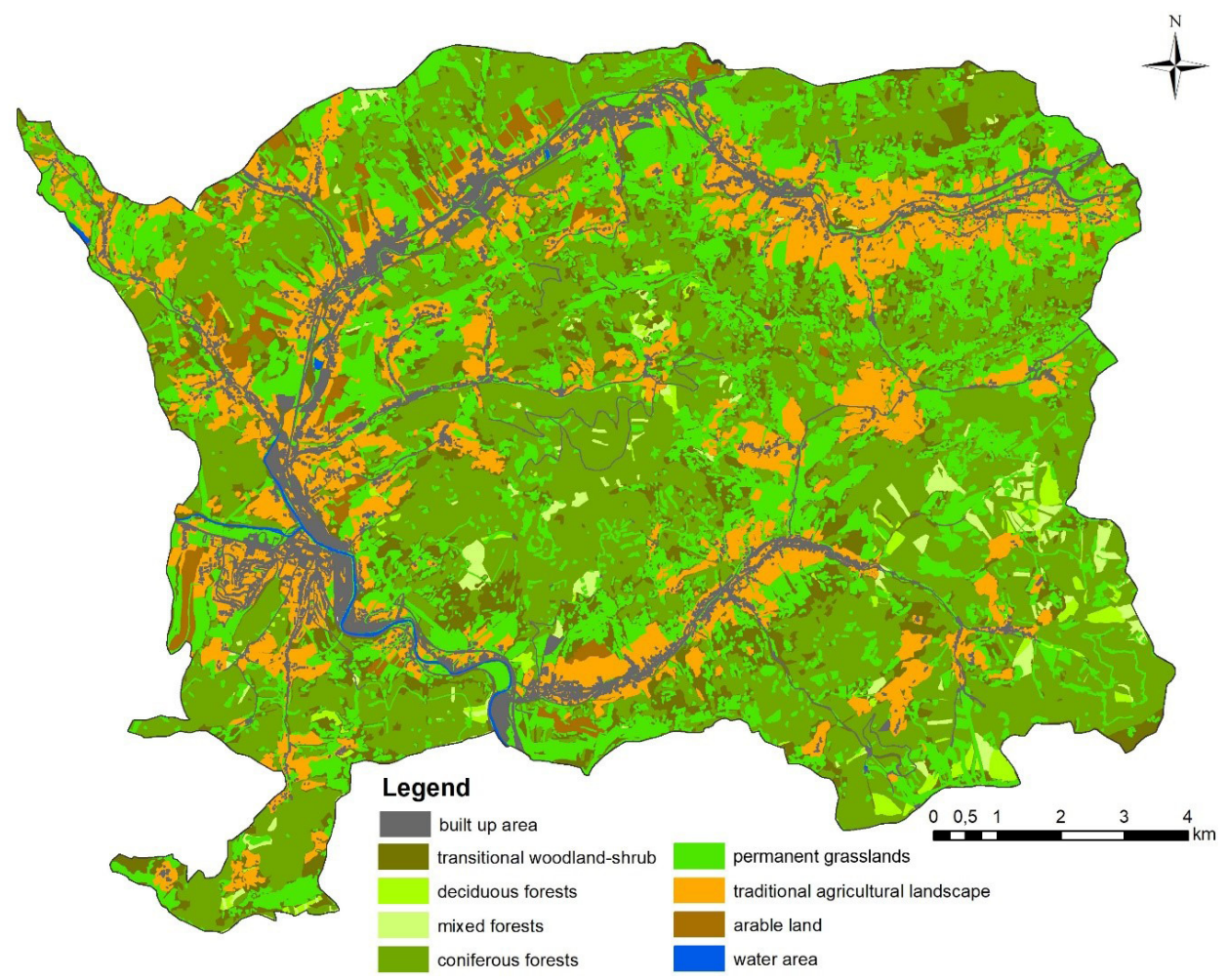

Fig. 1. Current landscape structure. 
The vector layer of occurring landslides was processed on the basis of the State Geological Institute of Dionýz Štúr database (Šimeková et al., 2006; updated in 2013) and field vitrificated (Fig. 2). According to the activity, the landslides were divided into three categories: active, potential and stabilized. The active (live) landslide is one that is currently moving. If movement is currently calm, but the causes of its formation can be restored under appropriate conditions, then it is a potential (temporarily calm) landslide. In a stabilized (permanently calm - inactive) landslide, the causes of movement have ceased to exist or have been removed by human intervention. Their significance is currently lower from a societal point of view, but their re-activation in connection with various activities cannot be eliminated, for example, construction of new buildings. Monitoring at these sites is predominantly maintenancerelated, but if necessary, its range and frequency may increase and sites may be upgraded to a higher significance category. Vector layer synthesis was processed by the union tool in ArcGIS 10.3.

The next step in the evaluation was to determine the overall threat to land by landslides. In this assessment, the basis was the representation of landslides in individual cadastral areas and the representation of landslides in individual elements of the landscape structure (expressed as a percentage). On the basis of this, we have created three levels of threat: 1 - low level of landslide threats, 2 - medium level of landslide threats and 3 - high level of landslide threats. To assess the risk of landslides in individual cadastral areas, a following scale was used: threat level 1 - interval $<0 \%, 2 \%$ ); threat level 2 - interval $<2 \%, 6 \%$ ); threat level 3 - above $6 \%$ resp. interval $<6 \%, 14 \%>$. To assess the risk of landslides in individual elements of the landscape structure, a following scale was used: threat level 1 - interval <0\%, 12\%); threat level 2 - interval <12\%, 24\%); threat level 3 - above $24 \%$ resp. interval $<24 \%, 36 \%>$.

The last step in the evaluation was to determine the limits of spatial planning resulting from the natural conditions of the monitored area, the character of the elements of the current landscape structure and the occurrence of landslides.

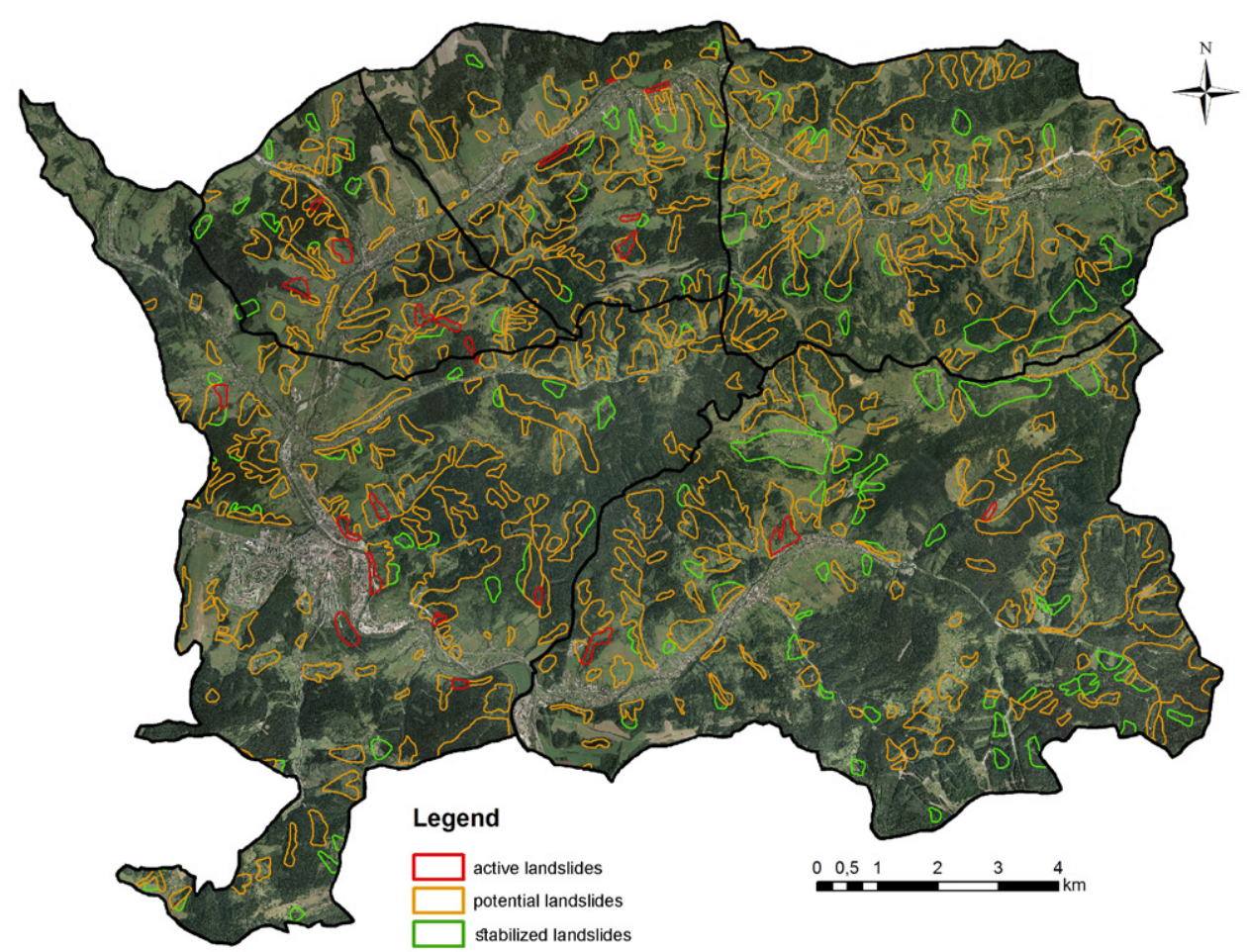

Fig. 2. Extension of individual landslides in the monitored area (processed according to Šimeková et al., 2006 and updated in 2013). 


\section{Study area}

The monitored area of the Kysuce region is located in the northern part of Slovakia (Fig. 3). It consists of five cadastral areas (CAs) (Čadca, Oščadnica, Svrčinovec, Čierne and Skalité) and is characterized by the diversity of abiotic and biotic components of the landscape. Based on the classification of Slovakia into geomorphological units (Mazúr, Lukniš, 1986), the area belongs to three territories: Central Beskids with units: Kysucká vrchovina Uplands and Kysucké Beskydy Mts, Western Beskids with units: Moravian-Silesian Beskids, Jablunkovské medzihorie Mts and Turzovská vrchovina Uplands and Slovak-Moravian Carpathians with unit Javorníky Mts.

The whole monitored territory has an area of $185.14 \mathrm{~km}^{2}$. The most extent geomorphologic unit in the territory is Kysucké Beskydy Mts, which occupy up to $100 \mathrm{~km}^{2}$ and the Jablunkovské medzihorie Mts with an area of $52 \mathrm{~km}^{2}$. Hilly to mountainous character of the landscape dominates with the altitude of $500 \mathrm{~m}$ to $1236 \mathrm{~m}$ a.s.l. Slopes with inclination from $12^{\circ}$ to $17^{\circ}(36.8 \%)$ and from $7^{\circ}$ to $12^{\circ}(26.1 \%)$ cover the largest area. From the geological aspect, the area consists of flysch, of which, the largest representation has the Vsetín member (Bystrica-type claystones, sandstones with glauconite, arcoses and conglomerates) with an area of $75.5 \mathrm{~km}^{2}$, Oščadnica member (green-gray shales, arcose-, quartzy- and graywacky sandstones) with an area of $14.5 \mathrm{~km}^{2}$ and Kýčera member (graywacky sandstones, locally shales) with an area of $12.4 \mathrm{~km}^{2}$. Dystric cambisol covers the largest area $-44.0 \%$ of the area and modal cambisol covers $31.1 \%$ of the area. The most widespread are forests and woodland-shrubs covering up to $56.5 \%$ of the area, of which coniferous forests cover $39.7 \%$ of the area. Agricultural land covers $38.0 \%$ of the area. In terms of precipitation, the area belongs to a humid climate zone. Average annual rainfall sums from Čadca, between 1994 to 2016 reach $700-1110 \mathrm{~mm}$. The highest average monthly precipitations occur from May to July. Between 2000 to 2017, the monthly precipitation in July was $130 \mathrm{~mm}$.

There are up to 475 registered landslides in this area, which make this area very vulnerable in terms of environmental hazards occurrence. Landslides occupy almost $1 / 4$ of the area $\left(44.14 \mathrm{~km}^{2}\right)$. Most of them are potential landslides, $331\left(35.52 \mathrm{~km}^{2}\right)$, then stabilized landslides, $124\left(7.54 \mathrm{~km}^{2}\right)$ and 20 active landslides $\left(1.08 \mathrm{~km}^{2}\right)$. Potential landslides cover $80 \%$ of the area of all landslides. The largest potential landslides (with an area of $1.5 \mathrm{~km}^{2}$ and 0.9 $\mathrm{km}^{2}$ ) are located in the Oščadnica village.

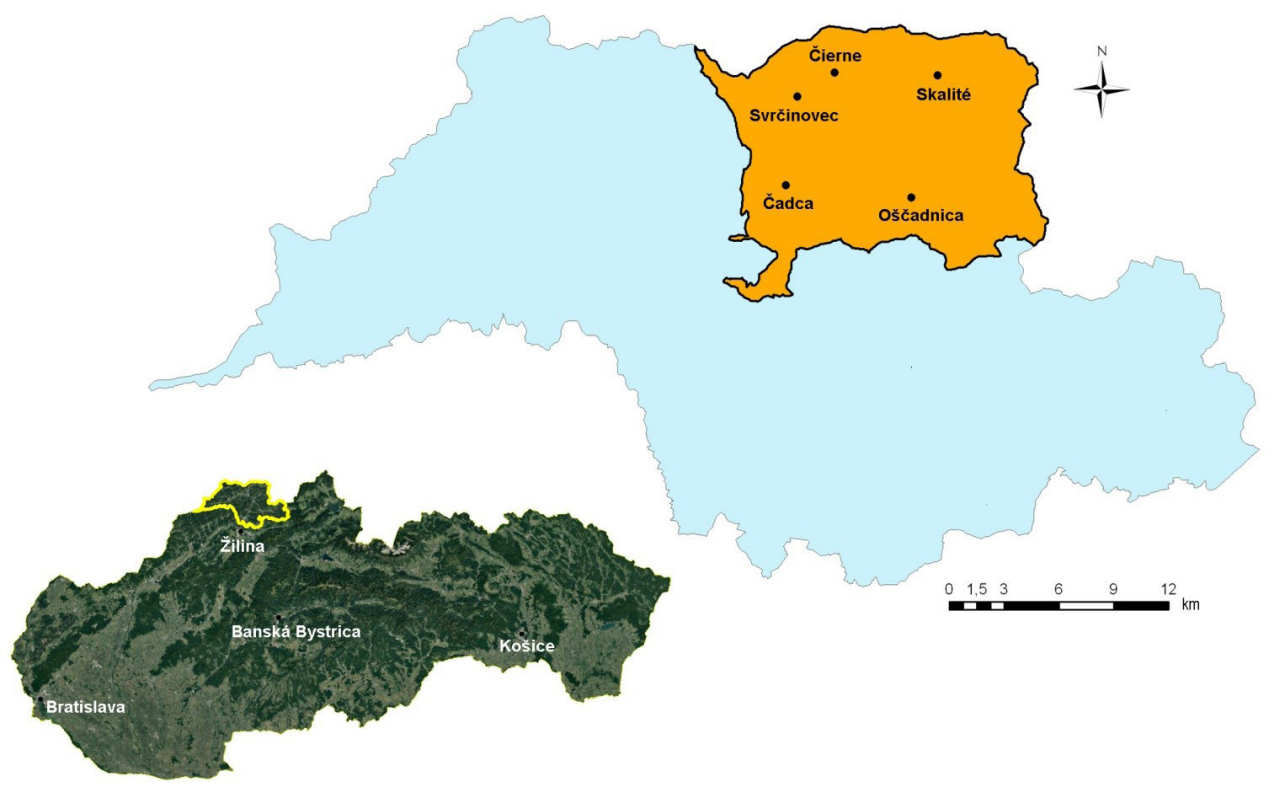

Fig. 3. Localization of study sites. 


\section{Results and discussion}

Spatial planning addresses the spatial layout and functional use of land. Landslides represent one of the limits of land use. They determine the coordination of activities affecting the environment, ecological stability, territorial development and landscape formation in accordance with the principles of sustainable development. Spatial planning creates the preconditions for the permanent consistency of all activities in the area, with particular regard to the environment cultivation. The goal of spatial planning is to create preconditions for sustainable development through a consistent and comprehensive solution of the spatial layout of the territory and the functional use of the territory.

\section{a) Built up area (structure)}

The continuous built up area is concentrated in the monitored territory mainly along the Kysuca, Čierňanka, Skaličianka and Oščadnica watercourses. Its total area is 798.52 ha. $12.02 \%$ (95.98 ha) of buildings are affected by landslides, of which $9.99 \%$ are potential landslides, $0.63 \%$ active landslides and $1.40 \%$ stabilized landslides (Table 1). Family houses (6\%), sheds $(2 \%)$, garages $(0.5 \%)$ and cabins $(0.6 \%)$ are most endangered by landslides. The most active landslides within the built up area are in the Čadca cadastral area (CA), where they occupy 3.19 ha. Built up areas in Svrčinovec CA are most threatened by potential landslides, on the area of 17.82 ha (Fig. 4). Of the total landslide area (4414.26 ha), $2.17 \%$ of landslides are in the built up areas.

\section{b) Forest stands}

Coniferous forests have the largest representation of all the forest stands (8000.42 ha), covering 7343.07 ha. There are potential landslides on $21.45 \%$ of the forest area $(1687.51 \mathrm{ha})$. The stabilized landslides cover 300.33 ha and active landslides cover 20.07 ha. In coniferous forests, potential landslides (1578.93 ha) cover the largest area, accounting for $78.64 \%$ of all landslides in forest stands. Stabilized landslides in coniferous forests occupy 283.88 ha and active landslides cover 20.07 ha. Deciduous and mixed forests have less representation in the area. Mixed forests cover an area of 430.92 ha and deciduous forests occur on an area of 226.43 ha. Potential or stabilized landslides have been recorded on these sites, as shown in Table 1.

Forest stands have the largest representation in the Oščadnica CA (3027.54 ha) and Čadca CA (2406.32 ha), and they cover the smallest area in the CA of Svrčinovec (only 521.94 ha). In terms of the extension of landslides in the monitored area according to the cadasters and individual types of forest stands, it can be stated that the largest occurrence have potential landslides in coniferous forests (Fig. 5). Potential landslides in coniferous forests in the Oščadnica CA have the largest representation, where they are on 522.92 ha (which is up to $31 \%$ of all potential landslides in the forests of the area) and Cadca CA, where they occupy 445.29 ha (26\% of all potential landslides in the forests of the area). They are less represented in the Skalité CA (292.20 ha, which is 17\%), Čierne CA (209.17 ha, 12\%) and at least 


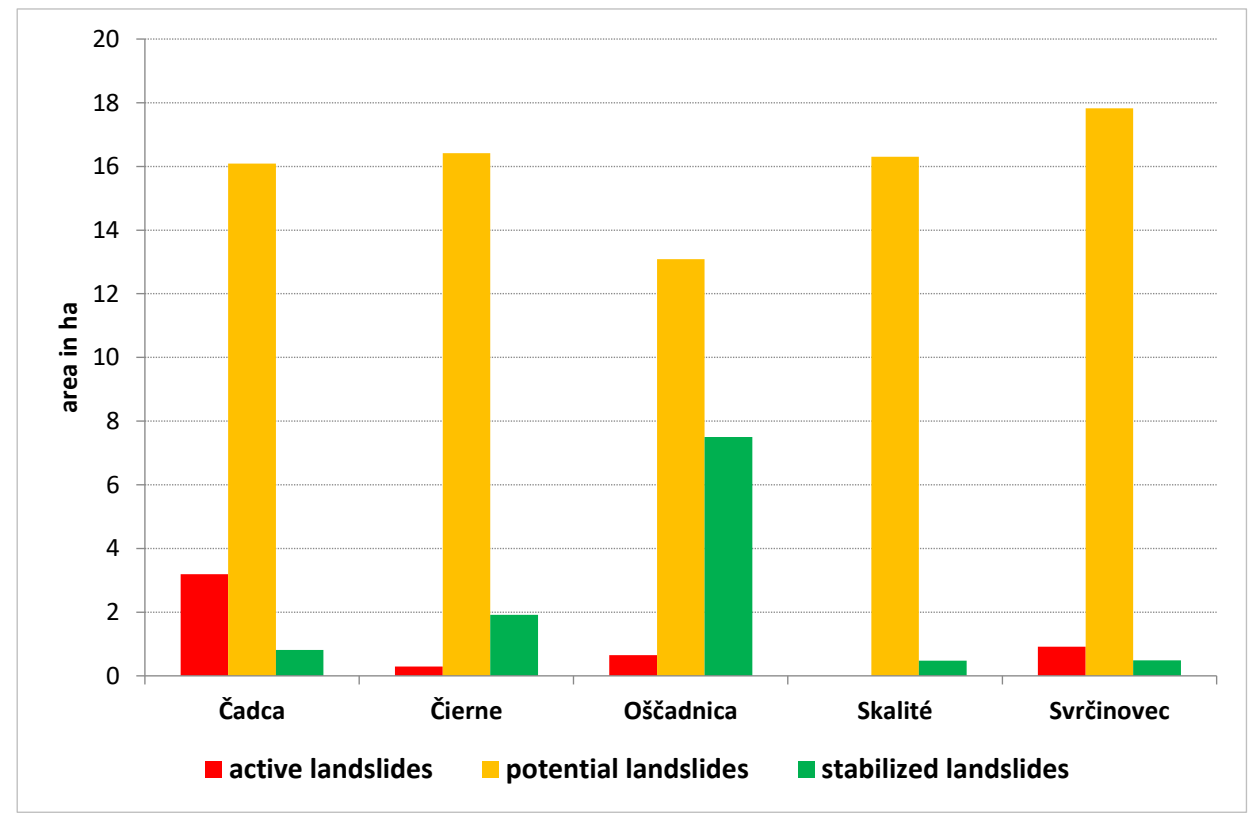

Fig. 4. Representation of landslides in the built up areas of individual cadastral areas.

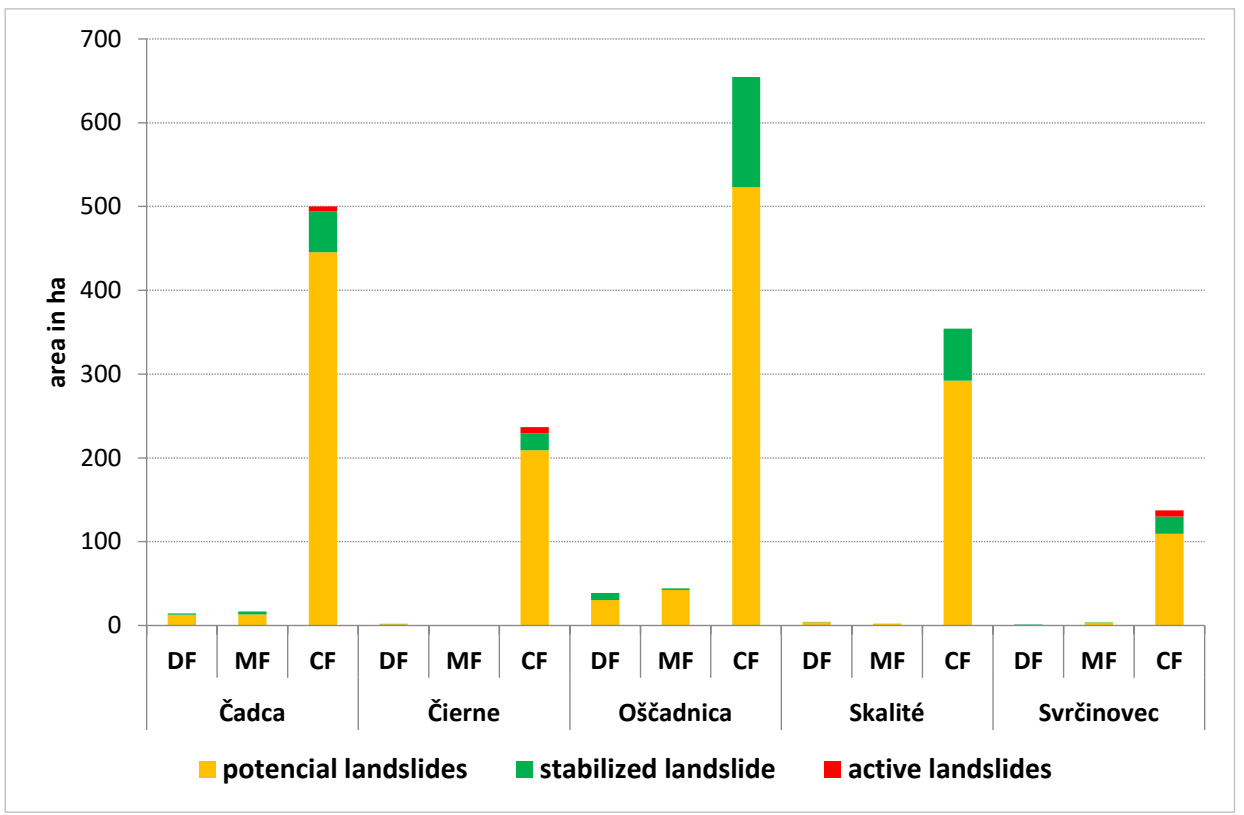

Fig. 5. Representation of landslides in individual types of forest stands in cadastral areas (DF - deciduous forests; $\mathrm{MF}$ - mixed forests; CF - coniferous forests). 
Svrčinovec CA, where they occupy 109.35 ha (which is $6 \%$ of all potential landslides in the forests of the area).

In deciduous and mixed forests, potential landslides have a much smaller occurrence, for example, in Oščadnica CA, they occur in the deciduous forests on an area of 30.21 ha and in mixed forests on an area of 42.39 ha, which together represents $4.3 \%$ of all potential landslides in the forests of the area. In Čadca CA, potential landslides are represented in deciduous forests on an area of 12.74 ha and in mixed forests on an area of 13.17 ha, which makes up $1.5 \%$. The other CAs - Čierne, Skalité and Svrčinovec have only a very small occurrence of potential landslides in deciduous and mixed forests (Fig. 5).

A similar situation is also in the case of distribution of stabilized landslides in individual forest types. The largest representation is in the Oščadnica CA., where they occupy 131.75 ha (which represents almost $44 \%$ of all stabilized landslides in the forests of the area). They are still quite often found in the forests of Skalité and Čadca CAs, less represented in the CAs Svrčinovec and Čierne.

Active landslides have the least representation in the forests of the monitored area. In the territory of the cadasters of Oščadnica and Skalité, they were not recorded at all, and in the territory of the cadasters of Čadca, Čierne and Svrčinovec, they were only in the areas of coniferous forests (Fig. 5). There they cover the areas of $5.62 \mathrm{ha}$ (Čadca), 7.10 ha (Čierne) and 7.36 ha (Svrčinovec), which are small areas compared to other landslides.

\section{c) Transitional woodland-shrub}

Transitional woodland-shrubs cover 2463.21 ha in the monitored area, of which $24.66 \%$ are located on landslides. The largest area is occupied by landslides on the areas of woodlandshrubs in the Oščadnica CA, where all three types of landslides occupy up to 171.10 ha, which is $28 \%$ of landslides on woodland-shrub areas. It is similar in the Čadca CA, where landslides cover 161.65 ha (26\%) and in Skalité CA, where landslides cover 146.91 ha (24\%). In other areas of Čierna and Svrčinovec, there are fewer landslides (Fig. 6).

Potential landslides are most widespread in the Čadca and Oščadnica CAs (126.98 ha and $126.42 \mathrm{ha}$ ). The same applies to active landslides, where the largest area occupies CAs of Čadca (12.85 ha) and Oščadnica (7.20 ha). Active landslides were not recorded in Skalité CA (Fig. 6).

\section{d) Traditional agricultural landscape}

In the monitored area, the elements of traditional agricultural landscape (TAL) occupy 2802.72 ha and landslides cover 718.21 ha in total (which is $25.63 \%$ of their area - a quarter of their area). Overall, the largest area of all landslides is in Oščadnica CA (225.17 ha, which represents $36 \%$ of landslides in a given land unit), it is slightly less in Skalité CA (188.26 ha, 26\%) and Čadca CA (160.32 ha, 22\%).

Active landslides occupy a total of 25.65 ha, of which most are in Oščadnica CA (8.05 ha), Čadca CA (7.95 ha) and in Svrčinovec CA (7.35 ha). Potential landslides have the largest share in the CAs Skalité (166.68 ha) and Čadca (140.89 ha). Stabilized landslides occupy the largest area in Oščadnica CA (88.30 ha) (Fig. 7). 


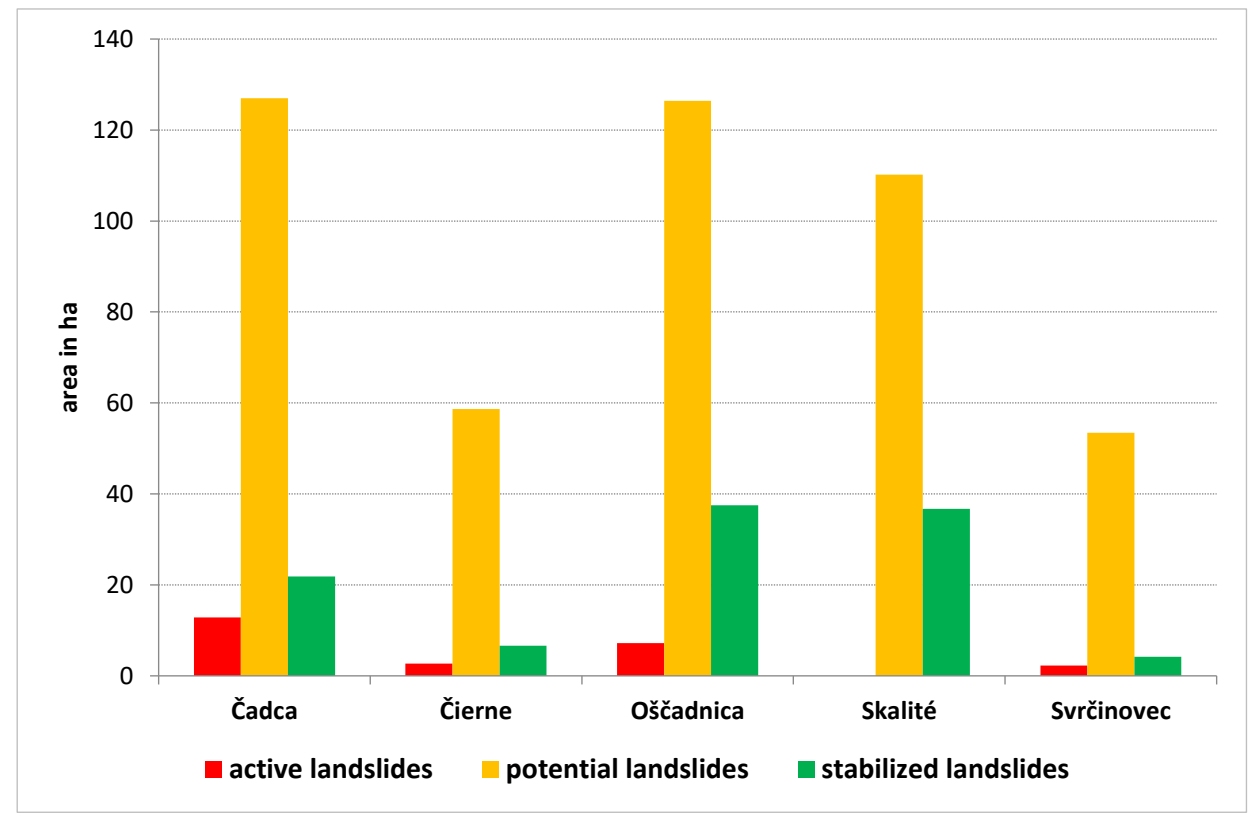

Fig. 6. Representation of landslides in the areas of woodland-shrub in individual cadastral areas.

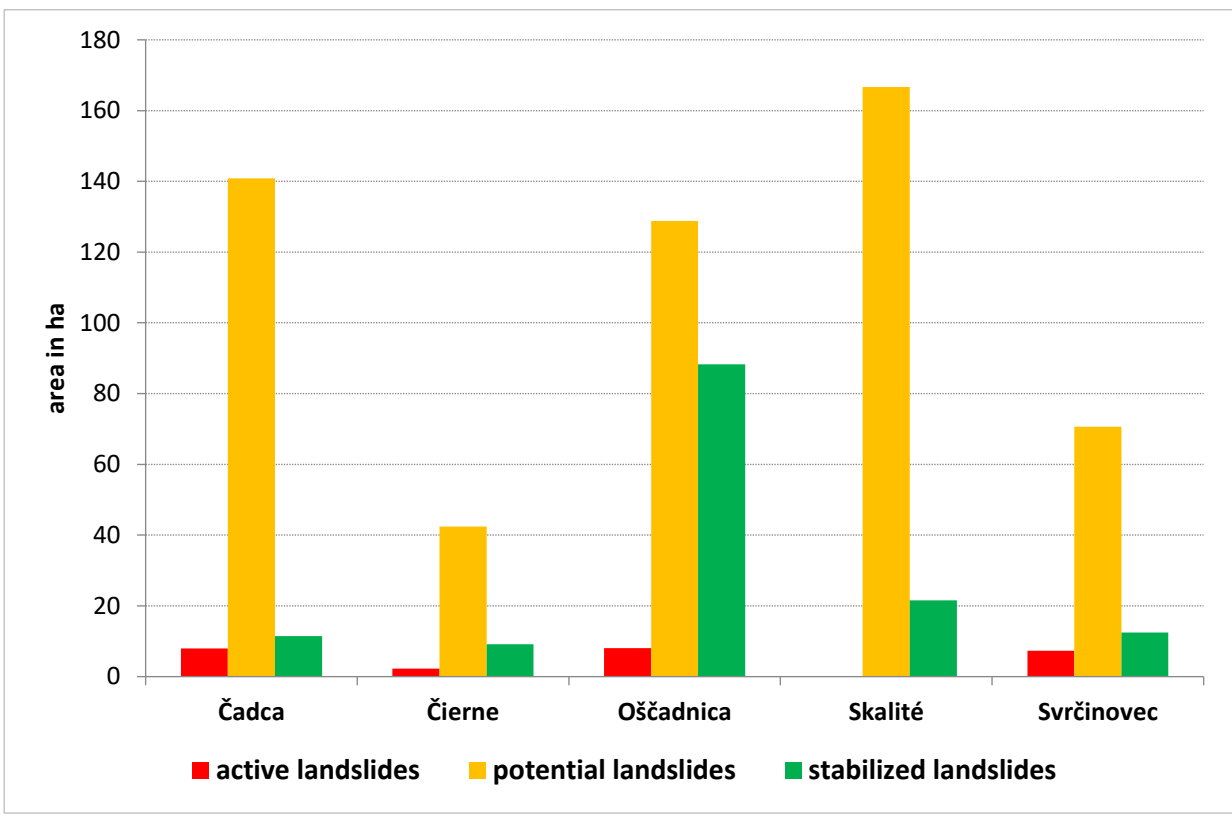

Fig. 7. Representation of landslides in the areas of traditional agricultural landscape elements in individual cadastral areas. 


\section{e) Permanent grasslands}

Permanent grasslands (PG) cover an area of 3914.86 ha, of which 965.76 ha are disturbed by landslides (which is $24.68 \%$ of the area of PG in the territory). Overall, the highest rate of landslides is in Skalité CA, where landslides occur on 289.22 ha, in CA Oščadnica landslides cover 275.75 ha and in Čadca CA landslides are on 188.62 ha.

Potential landslides represent the largest area. Potential landslides affect 741.33 ha (which is almost $77 \%$ of the total landslide area of PG), most of which are in CAs of Skalité (216.28 ha) and Oščadnica (192.64 ha). Stabilized landslides cover 192.44 ha (20\% of the total landslide area on PG), with the largest area in CAs of Oščadnica (73.24 ha) and Skalité (72.94 ha). By active landslides, 31.99 ha are disturbed (3\% of the total landslide area on PG). The largest active landslides are in Svrčinovec, Čadca and Oščadnica CAs, having the areas of 10.52, 10.42 and 9.88 ha, respectively.

\section{f) Arable land}

Arable land occupies the smallest area of all monitored landscape elements in the territory, only 311.36 ha. The landslides occur on an area of 18.93 ha of arable land, which is only $6.08 \%$ of the area of arable land and there are mainly potential landslides. They occupy the largest area in the CAs Čierne (8.51 ha) and Svrčinovec (4.25 ha).

\section{Overall evaluation of landslides representation and evaluation of threat in the monitored area}

Landslides occupy about a quarter of their area in most of the selected landscape elements. They have a smaller share only in the areas of mixed forests, built up areas and the smallest share in the areas of arable land (Table 1, Fig. 10). However, the largest landslides occur in the areas of coniferous forests, smaller areas occupying the sites of PG, TAL and transitional woodland-shrubs. The lowest proportion and share have landslides on arable land.

Potential landslides cover the largest areas in all the selected landscape elements, where the largest areas occupy the coniferous forests (1578.93 ha) and permanent grasslands (741.33 ha). By evaluating the overall endangerment by landslides according to the degree of threat, we found that the greatest threat of landslides is in the Skalité and Svrčinovec CAs, the lowest threat is in the Čadca CA (Table 2).

The biggest threat of landslides is in forest stands and permanent grasslands, while the transitional woodland-shrubs and TAL are slightly less endangered. The least endangered is the arable land in all monitored cadasters (Table 2).

Forests in the monitored area occupy the largest area and the natural forest stands were most often preserved in localities that were not suitable for intensive use (e.g., for development or agricultural use) in terms of natural conditions and processes. Therefore forests cover the largest area of landslides area. Given the persistent threat of landslides, there is no expectation that the nature of their use will change.

In the past farming in Kysuce was dominated by sheep and cattle breeding and the associated use of meadows and pastures. Arable land has always been less represented and 


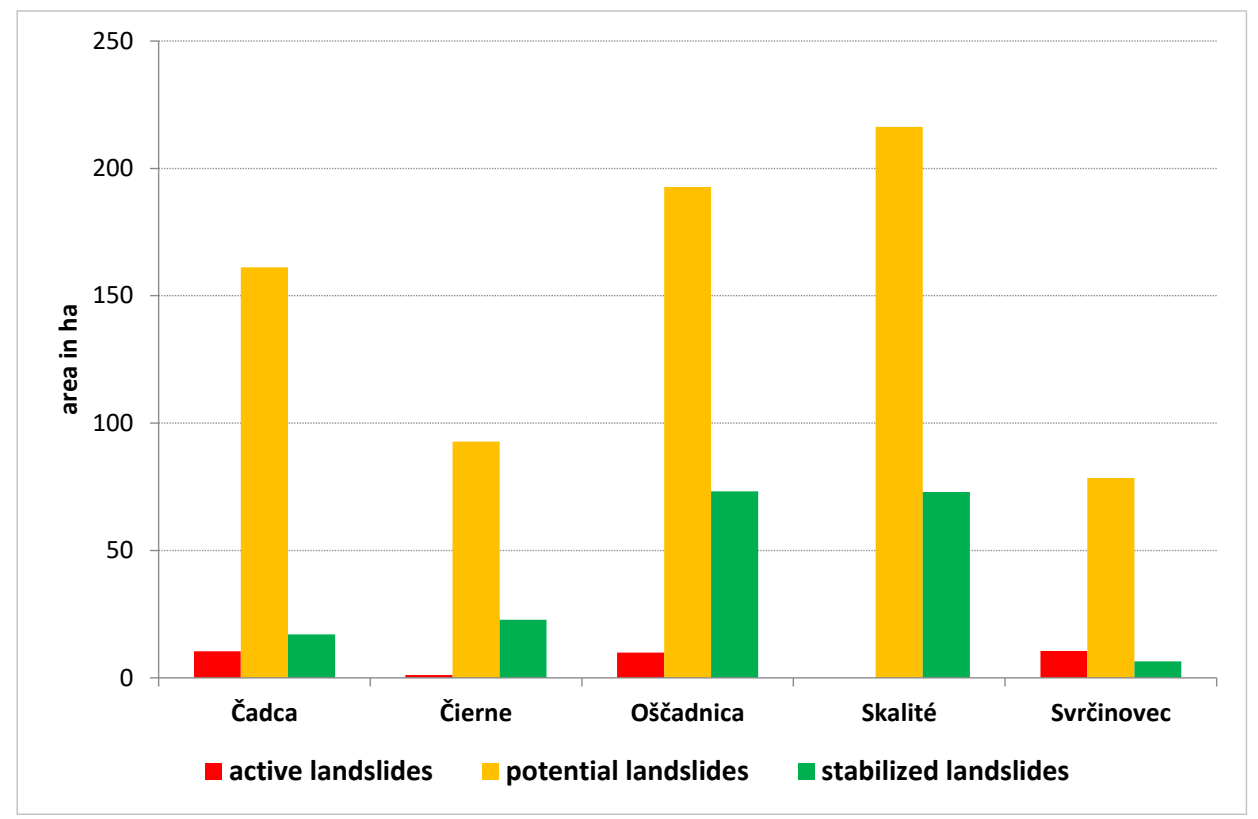

Fig. 8. Representation of landslides on permanent grasslands.

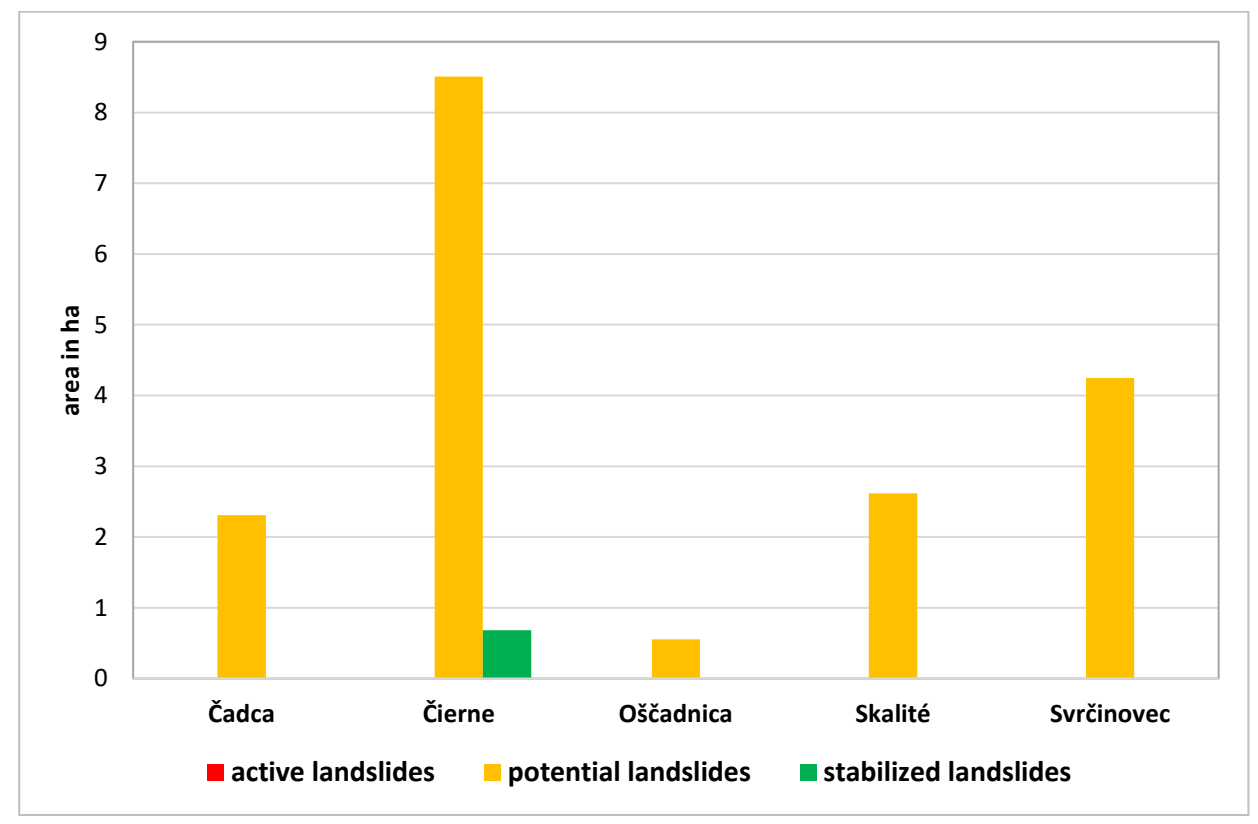

Fig. 9. Representation of landslides on arable land. 
T a b l e 1. Representation of individual landslides in the area.

\begin{tabular}{|c|c|c|c|c|c|}
\hline Elements of landscape structure & $\begin{array}{c}\text { Element } \\
\text { area } \\
\text { (ha) }\end{array}$ & $\begin{array}{c}\text { Active } \\
\text { landslides } \\
\text { (ha) }\end{array}$ & $\begin{array}{c}\text { Potential } \\
\text { landslides } \\
(\mathrm{ha})\end{array}$ & $\begin{array}{c}\text { Stabilized } \\
\text { landslides } \\
\text { (ha) }\end{array}$ & $\begin{array}{c}\text { Sum of } \\
\text { landslides } \\
(\%)^{*}\end{array}$ \\
\hline Built up area & 798.52 & 5.05 & 79.73 & 11.20 & 12.02 \\
\hline Deciduous forests & 226.43 & 0 & 46.89 & 10.63 & 25.40 \\
\hline Mixed forests & 430.92 & 0 & 61.69 & 5.82 & 15.67 \\
\hline Coniferous forests & 7343.07 & 20.07 & 1578.93 & 283.88 & 25.64 \\
\hline Transitional woodland-shrubs & 2463.21 & 24.99 & 475.65 & 106.83 & 24.66 \\
\hline Permanent grasslands & 3914.86 & 31.99 & 741.33 & 192.44 & 24.68 \\
\hline Traditional agricultural landscapes & 2802.72 & 25.65 & 549.51 & 143.05 & 25.63 \\
\hline Arable land & 311.36 & 0 & 18.24 & 0.69 & 6.08 \\
\hline Others & 222.91 & \multicolumn{4}{|c|}{ not evaluated } \\
\hline SUM & 18514.00 & 107.75 & 3551.97 & 754.54 & 24.14 \\
\hline
\end{tabular}

Note: ${ }^{*}$ - reflects the share of landslides in $\%$ of the total area of a given landscape structure element.

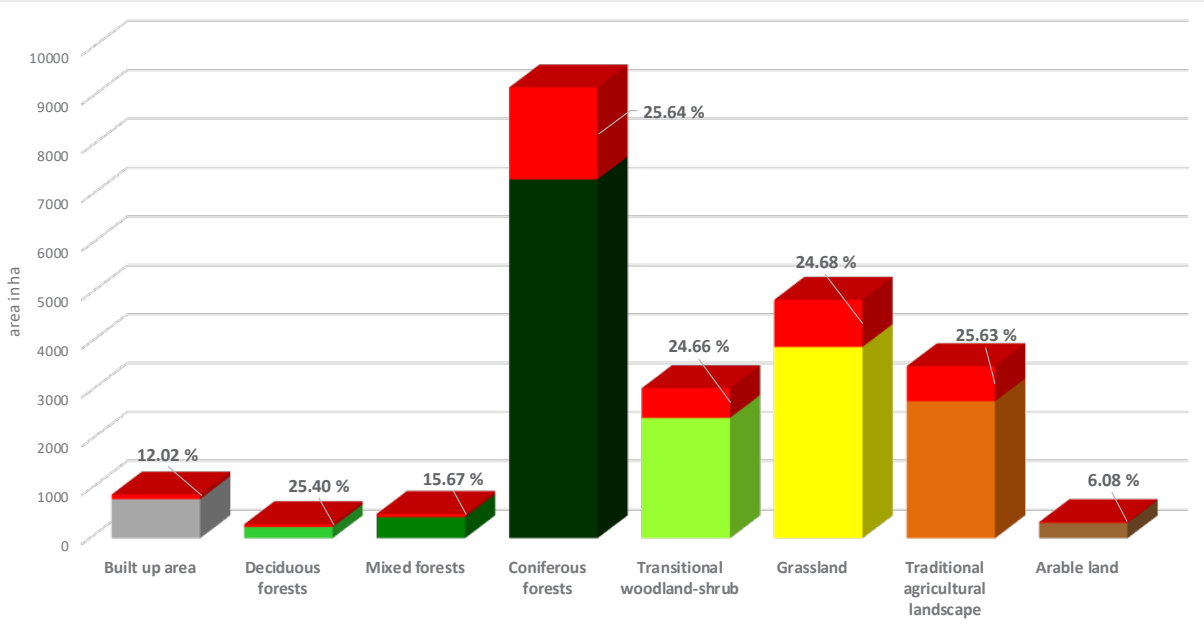

Fig. 10. Overall representation of landslides in the area.

crop production was focused on potato growing. Due to the hilly character of the area, small terraced fields prevailed. Cereal cultivation has always had a secondary position due to the climatic conditions of the territory. That is why PG dominates in the monitored area on agricultural land and many TAL areas have been preserved up to now. At the time of intensive use of PG and TAL elements, man also took care of their protection against landslides (adjustment and stabilization of slopes, diversion of running water from sites, etc.). After the abandonment of farming in these areas, the influence of natural processes prevailed and the factors that activate the landslide processes often occur in these areas. 
$\mathrm{T}$ a b l e 2. Endangerment of the area by landslides.

\begin{tabular}{|c|c|c|c|c|c|c|c|}
\hline $\begin{array}{l}\text { Cadastral } \\
\text { area } \\
\text { (extent) }\end{array}$ & $\begin{array}{l}\text { Monitored } \\
\text { element }\end{array}$ & Built up area & $\begin{array}{l}\text { Forest } \\
\text { stands }\end{array}$ & $\begin{array}{c}\text { Transit. } \\
\text { woodland- } \\
\text { shrub }\end{array}$ & PG & TAL & Arable land \\
\hline \multirow{5}{*}{$\begin{array}{l}\text { Čadca } \\
(5679 \text { ha })\end{array}$} & $\operatorname{area}(\mathrm{ha})^{*}$ & 19.98 & 531.23 & 161.65 & 188.62 & 160.33 & 2.31 \\
\hline & share ${ }^{* *}(\%)$ & 0.35 & 9.35 & 2.85 & 3.32 & 2.82 & 0.04 \\
\hline & share $^{* * *}(\%)$ & 6.10 & 22.08 & 21.15 & 19.04 & 17.86 & 1.91 \\
\hline & threat in CA & 1 & 3 & 2 & 2 & 2 & 1 \\
\hline & threat in CLS & 1 & 2 & 2 & 2 & 2 & 1 \\
\hline \multirow{5}{*}{$\begin{array}{l}\text { Čierne } \\
\text { (2082 ha) }\end{array}$} & $\operatorname{area}(\mathrm{ha})^{*}$ & 18.51 & 238.46 & 67.98 & 116.69 & 53.98 & 9.19 \\
\hline & share ${ }^{* *}(\%)$ & 0.89 & 11.45 & 3.27 & 5.60 & 2.59 & 0.44 \\
\hline & share $^{* * *}(\%)$ & 14.63 & 24.04 & 27.77 & 23.25 & 23.54 & 11.37 \\
\hline & threat in CA & 1 & 3 & 2 & 2 & 2 & 1 \\
\hline & threat in CLS & 2 & 3 & 3 & 2 & 2 & 1 \\
\hline \multirow{5}{*}{$\begin{array}{l}\text { Oščadnica } \\
\text { (5863 ha) }\end{array}$} & $\operatorname{area}(\mathrm{ha})^{\star}$ & 21.12 & 737.96 & 171.10 & 275.75 & 225.17 & 0.56 \\
\hline & share ${ }^{* *}(\%)$ & 0.36 & 12.59 & 2.92 & 4.70 & 3.84 & 0.01 \\
\hline & share $^{* * *}(\%)$ & 13.64 & 24.37 & 22.52 & 24.58 & 31.88 & 1.51 \\
\hline & threat in CA & 1 & 3 & 2 & 2 & 2 & 1 \\
\hline & threat in CLS & 2 & 3 & 2 & 3 & 3 & 1 \\
\hline \multirow{5}{*}{$\begin{array}{l}\text { Skalité } \\
\text { (3316 ha) }\end{array}$} & $\operatorname{area}(\mathrm{ha})^{\star}$ & 16.67 & 360.47 & 146.91 & 289.22 & 188.26 & 2.62 \\
\hline & share $^{\star *}(\%)$ & 0.50 & 10.87 & 4.43 & 8.72 & 5.68 & 0.08 \\
\hline & share $^{* * *}(\%)$ & 17.34 & 34.24 & 27.94 & 31.42 & 28.68 & 22.00 \\
\hline & threat in CA & 1 & 3 & 2 & 3 & 2 & 1 \\
\hline & threat in CLS & 2 & 3 & 3 & 3 & 3 & 2 \\
\hline \multirow{5}{*}{$\begin{array}{l}\text { Svrčinovec } \\
\text { (1574 ha) }\end{array}$} & $\operatorname{area}(\mathrm{ha})^{*}$ & 19.11 & 142.65 & 59.85 & 95.49 & 90.47 & 4.25 \\
\hline & share $^{* *}(\%)$ & 1.21 & 9.06 & 3.80 & 6.07 & 5.75 & 0.27 \\
\hline & share $^{\star * *}(\%)$ & 20.45 & 27.33 & 35.50 & 25.13 & 28.91 & 6.99 \\
\hline & threat in CA & 1 & 3 & 2 & 3 & 2 & 1 \\
\hline & threat in CLS & 2 & 3 & 3 & 3 & 3 & 1 \\
\hline
\end{tabular}

Notes: ${ }^{*}$ - the total area of landslides in hectares located in the area of the given element of the landscape structure within the cadastral area; ${ }^{* *}$ - the proportion of landslides in \% within an element of the landscape structure to the total area of the cadastral area; ${ }^{* * *}$ - the proportion of landslides area in $\%$ to the total area of the element of the landscape structure within the cadastral area.

The continual reduction in the proportion of actively used areas of PG or arable land results in their overgrowth by natural seeding bushes, and in some areas, there are even continuous forest stands. This increases the significant proportion of this non-forest tree and shrub vegetation in the area among the elements of the current landscape structure. As in the case of PG and TAL, the impact of natural processes is increasing and also the susceptibility of the area to landslides is increasing.

At present, only a small area of arable land has been preserved and is still being used. It is situated in the valley part of the area or on gentle slopes, where the landslides occur only to a lesser extent and the favorable conditions for the formation of landslides develop to a much 
lesser degree. Therefore, the current threat to arable land is considerably less compared to other elements of the landscape.

When selecting areas for residential development, complicated areas are usually being avoided, so that the buildings and the lives of people are not endangered. Under certain conditions, however, there are signs of slope movement or they occur accidentally under significant environmental influences such as storm rainfalls, prolonged rains causing soil and subsoil supersaturation with water and so on. The development of settlements and the need to build new areas often come across the sites that are potentially susceptible to landslides.

\section{Limits of territorial development}

The overall development of the territory must be subject to certain rules, which should be included in the territorial plan. Based on the evaluation of landslides on the individual elements of the landscape structure and in individual cadastral areas, we determined the limits of the development in the monitored area. Spatial planning limits have been divided into two categories according to the sectors that are most influenced by these limits - limiting the development of land intended for residential development or limiting the development of land intended for agricultural and forestry use.

1. The limits of the territorial development designated for residential development are based on the given area conditions. natural conditions and factors causing landsliding. They are based on the following restrictions and warnings:

- new construction cannot be located in areas where there are active and potential landslides, including the additional construction and renovation of existing buildings;

- new construction in areas of stabilized landslides is possible only after the elaboration of geological and engineering documentation confirming that the proposed investment will not affect the balance of the territory and will not activate landslides;

- existing buildings in the areas of active, potential and stabilized landslides can be maintained and used with recommendations based on the elaborated geological and engineering documentation identifying the need to implement safety measures (e.g., dewatering the ground and surface water from a slope by building drainages. relocating soil from an overburdened landslide base or lightening the landslide in the upper part, construction of retaining walls and other geotechnical structures);

- unprofessional intervention into the disturbed slope can cause the slope movements to be activated (it can be, e.g., when the active parts by the weight of shallow imbedded objects and by building the embankment during landscaping and road construction);

- poorly stable slopes are damaged by disruption of their passive part during landscaping. by notches for buildings or roads and during construction of utility networks;

- negative changes in hydrogeological conditions on the slope also contribute to the disruption of slope stability, for example, long-term construction causes acceleration of rock weathering and erosion on slopes. 
2. The limited development of an agricultural and forestry area should be based on the following restrictions and warnings:

- arable and forest land management in areas with active and potential landslides without heavy machinery;

- the area with active and potential landslides should not be used as arable land, but only as meadows and pastures;

- utilization of contoured agrotechnics - usually associated with deep plowing and includes all common agrotechnical interventions, which are carried out in the direction of contour lines, or utilization of no-till farming (the most progressive protection measure against landslides);

- rational crop rotation - crop rotation with protective effect (e.g., use of multiannual fodder crops and grasses with very good protective effect from the beginning of the formation of closed stands up to its removal);

- planting of special-purpose agricultural and protective greenery, reduction of arable land blocks;

- stabilization of large grassy areas in territories with active and potential landslides in the form of woody vegetation dominated by scrub vegetation;

- do not use the clear-felling method in forest management and do not build roads in areas with active and potential landslides;

- the quality of bedrock has a great influence on the occurrence of landslides, the slopes on the flysch are most endangered (if the upper layers of rocks slide alongside the soil, the risk of landslide increases), climate conditions are also important, for example, short and violent thunderstorms cause shallow landslides, but longlasting rains of lower intensity cause deeper and more extensive landslides to which the forest is less resistant;

- the risk of shallow landslides in the forest can be mitigated by the roots of trees that reach deeper into the soil. trapping more firmly and permanently than roots of other plants, the roots of the trees penetrate through the soil layers to the bedrock and thus increase the slip resistance; the ability of the forest to dry the soil is also very important;

- as a protection against landslides, deep-rooting trees (e.g., pine, larch, oak, valuable deciduous trees) are suitable, although in real conditions (e.g., waterlogged soils), these trees can also create a shallow root system - suitable woody plants for individual habitats should be preferred;

- shallow rooted trees such as spruce (Picea abies) are more susceptible to landslides and it is not advisable to create continuous monocultural stands in landslide prone areas;

- crop density is also important - gaps in which there are no interweaving roots are more prone to landslides;

- slopes endangered by landslides should be used as permanent forests and natural forest regeneration should be preferred - natural regeneration in stands with a natural species composition often speeds up the creation of new stands;

- following the principles of forest protection and restoration with a natural species 
composition will mitigate the potential threat to areas that are currently endangered by large-scale logging and tree dying in monocultural spruce stands;

- forest roads that run across steep slopes can cause disruption of the stability; drainage of water off the road towards the hillside is dangerous, it is preferable to use indentation that drains water onto the embankment slope and into the forest;

- do not use heavy machinery when loading slopes, they can disrupt the soil and vibrations can cause the soggy soil to slip;

- landslides can also be caused by the use of explosives in road construction - explosion shocks can detach landslides.

Given the diversity of habitat conditions and land use, it is necessary to define conditions for the protection of land from landslides in individual sites, taking into account all their specific characteristics and conditions.

\section{Conclusion}

With the gradual urbanization and the increasing need for higher living comfort, developers are forced to deal with the evaluation of complex engineering-geological conditions in more detail when assessing not only ground, underground, line, but also other types of buildings. Proper placement of buildings with a thorough knowledge of the current state of the geological environment, but especially the anticipation of geological processes in the future, with an emphasis on geobarriers, can be a means of saving high financial costs for possible remediation in the future; and last but not least, it will increase the safety of the population.

Changing land use in the local zoning plan due to changing conditions is a complex process not only for the municipality but also for the landowner. Spatial planning within the municipality must identify areas of natural geological hazards and take into account the safety for its inhabitants and their property. It is necessary for municipalities to undertake appropriate activities in relation to the localization of hazards, in particular, the risks of formation of landslides and the prevention of investments in unsuitable areas.

Compensatory costs associated with land use change and decline in value appear to be negligible compared to the potential losses due to the occurrence of landslides in built-up and inhabited areas.

\section{Acknowledgements}

The contribution was prepared within the grant project of the Ministry of Education of the Slovak Republic and the Slovak Academy of Sciences No. 2/0132/18 "Historical and present changes in the landscape diversity and biodiversity caused by natural and anthropogenic factors".

\section{References}

Barančoková, M. \& Kenderessy P. (2014). Assessment of landslide risk using GIS and statistical methods in Kysuce region. Ekológia (Bratislava), 33(1), 26-35. DOI: 10.2478/eko-2014-0004

Bathrellos, G.D., Kalivas, D.P. \& Skilodimou H.D. (2009). GIS-based landslide susceptibility mapping models applied to natural and urban planning in Trikala, Central Greece. Estud. Geol., 65(1), 49-65. DOI: 10.3989/egeol.08642.036. 
Bydłosz, J. \& Hanus P. (2013). The impact of landslide areas on municipal spatial planning. Real Estate Management and Valuation, 21(4), 5-10. DOI: 10.2478/remav-2013-0031

Carrara, A., Giovanni, C. \& Frattini P. (2003). Geomorphological and historical data in assessing landslide hazard. Earth Surface Processes and Landforms, 28, 1125-1142. DOI: 10.1002/esp.545.

Cascini, L., Bonnard, Ch., Corominas, J., Jibson, R. \& Montero-Olarte J. (2005). Landslide hazard and risk zoning for urban planning and development. In O. Hungr, R. Fell, R. Couture \& E. Eberhardt (Eds.), Landslide risk management (pp. 199-235). London: Taylor \& Francis Group.

Guillard, C. \& Zêzere J.L. (2012). Landslide susceptibility assessment and validation in the framework of municipal planning in Portugal: the case of Loures municipality Environ. Manag., 50, 721-735. DOI: 10.1007/s00267012-9921-7.

Lan, H.X., Zhou, C.H., Wang, L.J., Zhang, H.Y. \& Li R.H. (2004). Landslide hazard spatial analysis and prediction using GIS in the Xiaojiang watershed, Yunnan, China. Engineering Geology, 76, 109-128. DOI: 10.1016/j. enggeo.2004.06.009.

Lekkas, E. (2000). Natural and technological disasters destructions. Athens: Access Pre-press.

Malgot, J. \& Baliak F. (2002). The influence of human activity on the development of landslides in Slovakia. Geografický Časopis, 54(1), 21-38.

Mancini, F., Ceppi, C. \& Ritrovato G. (2010). GIS and statistical analysis for landslide susceptibility mapping in the Daunia area, Italy. Natural Hazards and Earth Systems Science, 10, 1851-1864. DOI: 10.5194/ nhess-10-1851-2010.

Mazúr, E. \& Lukniš M. (1986). Geomorfologické členenie SSR a ČSSR. Čast’ SSR. 1:50 000. Bratislava: Slovenská kartografia.

Mihai, B., Savulescu, I., Sandric, I. \& Chitu Z. (2014). Integration of landslide susceptibility assessment in urban development: a case study in Predeal town, Romanian Carpathians. Area, 46(4), 377-388. DOI: 10.1111/ area.12123.

Nowak, A. \& Tokarczyk N. (2013). Evaluation of soil resilience to anthropopressure in Łosie village (Lower Beskids Mts) - preliminary results. Ekológia (Bratislava), 32(1), 138-147. DOI: 10.2478/eko-2013-0012.

Řehák, D., Sikorová, K. \& Senovský P. (2013). Safety assessment for spatial development. Ekológia (Bratislava), 32(2), 220-241. DOI: 10.2478/eko-2013-0019.

Šimeková, J., Martinčeková, T., Abrahám, P., Gejdoš, T., Grenčíková, A., Grman, D., Hrašna, M., Jadroň, D., Záthurecký, A., Kotrčová, E., Liščák, P., Malgot, J., Masný, M., Mokrá, M., Petro, L., Polaščinová, E., Solčiansky, R., Kopecký, M., Žabková, E., Wanieková, D., Baliak, F., Caudt, L., Rusnák, M. \& Sluka V. (2006). Atlas máp stability svahov SR v mierke 1: 50 000. Záverečná správa. Bratislava: Geofond, MŽP SR. 